\title{
Metazoa and Related Diseases
}

\author{
Santiago Pascual, Elvira Abollo, Ivona Mladineo, and Camino Gestal
}

\begin{abstract}
Cephalopods and their metazoan parasites have coevolved in wild fisheries for many years. In fact, helminth larvae and parasitic copepods have been recorded in cephalopods worldwide. This is not surprising considering the important role cephalopods play in the transfer of energy and contaminants in marine food webs. Nerito-oceanic ommastrephid squids are by far the most noticeable trophic bridge for helminth parasites in the marine realm, coastal octopus, and cuttlefish serving as primary host for crustaceans. Although it is highly likely that parasitic infections occurred, relatively little is known about the pathogenic potential of metazoan parasites in naturally infected cephalopods. It is stated that heavy parasitic infections may probably cause host morbidity or poor condition but signs of disease are singularly rare with very few specimens exhibiting disease conditions. Unfortunately, neither robust scientific evidence nor available material is available to support this statement. It is more likely that metazoans may deplete energy stores of infected cephalopods, which are directed toward tissue repair and the host's defense mechanisms. Parasitic infection may thus be considered an environmental stressor and as such a source of uncertainty in the evaluation of the potential productivity of cephalopod populations.
\end{abstract}

\section{Keywords}

Metazoan parasites - Pathogens - Trematodes - Cestodes - Nematodes - Crustaceans • Seafood security

S. Pascual ( $\square)$

Ecology and Biodiversity Department, Institute of Marine

Research, Spanish National Research Council (CSIC), 36208

Vigo, Pontevedra, Spain

e-mail: spascual@iim.csic.es

E. Abollo

Centro Tecnológico del Mar, Fundación CETMAR, 36208

Vigo, Pontevedra, Spain

e-mail: eabollo@cetmar.org

I. Mladineo

Institute of Oceanography and Fisheries, 21000 Split, Croatia

e-mail: mladineo@izor.hr

C. Gestal

Aquatic Molecular Pathobiology Group, Institute of Marine

Research, Spanish National Research Council (CSIC), 36208

Vigo, Pontevedra, Spain

e-mail: cgestal@iim.csic.es

\subsection{Introduction}

Metazoan parasites comprise a polyphyletic group made up of six parasitic taxa: flatworms (Platyhelminthes), tapeworms (cestodes), trematodes (flukes), roundworms (nematodes), acanthocephalans, and crustaceans. They exhibit complex life cycles and reproductive strategies, with a remarkable high diversity and prevalence in marine ecosystems. Ecto- and endoparasitic metazoans including monoxenous/heteroxenous and specialist/generalist species have been largely recorded in the different components (zooplankton, fish, large fish, marine mammals, and seabirds) of the trophic cascades characteristically defined in the marine realm (Rohde 2002). 
Recently, spatially explicit modeling revealed that European cephalopod distributions match contrasting trophic pathways (Puerta et al. 2015), and therefore it is expected that cephalopods are common hosts for metazoan parasites. Such statement is not surprising considering that cephalopods are key element in the food web, its foraging behavior and diet facilitates endoparasite transmission. Furthermore, cephalopods inhabit in a wide array of biotopes (shallow to deeper waters)/ecosystems (benthic to pelagic), and its varied social structure and behavior capabilities (solitary, scholar) may also enable an ectoparasitic recruitment into major cephalopod stocks. The above both arguments provide us a broad perspective to understand the great availability of ubiquitous microhabitats offered by cephalopods to colonization by metazoan parasites. In fact, the reported species composition of the metazoan fauna-infecting cephalopods being characterized by a relatively uniform and limited composition remains far from saturated, with empty microniches to be colonized.

The general qualitative character of the metazoan fauna of European Atlantic populations of octopus/cuttlefish/squid (coastal-slope species) and short-finned squid (slope-shelf and nerito-oceanic species) is almost the same as that of Mediterranean populations; only a few differences in species composition were observed, which clearly reflects that infection by metazoans (mostly at larval stage) are nonspecific. Overall, the community structure of parasitic metazoans of European cephalopods is similar among ecologically and taxonomically close species. On the basis of 2000 individuals comprising 10 cephalopod species collected at a microgeographic area (Galician waters, NW Spain), González et al. (2003) found some associations between parasite relative species diversity and cephalopod life cycle characteristics. Results showed that those species with similar risk of becoming infected with a given parasite fauna belong to one of three ecological groupings (coastal, intermediate, or nerito-oceanic). It was suggested that the ecological niche of a cephalopod species is more important in determining its risk of parasitic infection than is phylogeny.

Mostly, the narrow range of metazoan parasites found in European cephalopod populations is thus characterized by wide host specificity. In the life cycles of the reported parasitic helminths, cephalopods may be considered second intermediate or transport/paratenic hosts serving as trophic bridges for parasite flow to top predators (final hosts) (Pascual et al. 1996a; Abollo et al. 1998).

Moreover, the composition of the parasitocoenoses of European cephalopods seems to remain stable over time. Another issue is the marked differences noted in the infection rate. The demographic infection parameters of a given cephalopod species within a particular ecological group may vary among ecoregions and even province of a particular European marine realm. As a rule, infections by metazoan parasites are significantly higher in northern European seas and Lusitanian provinces than in the Mediterranean basin. Furthermore, the size/weight/sexual maturity structure of a given cephalopod grouping is recognized as the key categorical predictor of parasite epidemiological values determining the intra- and interspecific variability of the metazoan fauna of European cephalopod stocks. Generally, no significant differences in the infection rate of males and females are observed, but as the size/weight/maturity increase the infection values substantially raise. Additionally, parasite recruitment may vary depending on the definitive host distribution (Kuhn et al. 2016) but especially, at the mesoscale, the recruitment in the mesozooplankton and hyperbenthos are affected by the oceanographic regime (Pascual and González 2007; Gregori et al. 2015). The latter authors gave evidence that at in upwelling systems parasite faunas are impoverished, whereas downwelling relaxing conditions propitiate optimal conditions to successful. Similarly, ontogenetic shifts in cephalopod diet from planktonic invertebrates and small fish planktophages on one side to largest fish preys on the other may contribute to age-related variations in the helminthofauna (from trematodes to cestodes/nematodes). These shifts may also enhance the accumulation process of parasites which largely favors the typical skewed binomial distribution of metazoans in cephalopod populations.

Fragmentary information on the metazoan fauna of European cephalopods based on opportunistic sampling plans within commercial fisheries or market surveys has been produced in 20 papers published in the last 30 years accounting from the latter revision provided by Hochberg (1990). This knowledge progress made on the biodiversity, pathology, and ecological relationships of metazoan parasites affecting cephalopods reflects a poor coverage for species/geographical areas. There can be no doubt of the lack of sufficient critical mass of European scientists in this field, but in a comparative analysis with other commercially important taxa, a historical negligible financial support for research on cephalopod diseases animal group was noted (Pascual and Guerra 2003). The rate of knowledge progress on cephalopod diseases becomes, therefore, a vexing, unbalanced question in fisheries research.

There is, nevertheless, some current regional and national surveillance plans for zoonotic parasites implicated in human allergy (following the scientific opinion on parasite risk in fishery products published by the European Food Safety Authority; EFSA 2010) which may serve as a promising platform for future biodiversity studies on metazoan parasites of cephalopods. The use of already certified biobanking tools in fish parasite research (González et al. 2018) can also aid to establish network opportunities for sampling and collection of traceable metazoan cephalopod parasites.

Against the overall background, the strategy defined in this chapter is not to make a comprehensive literature review of host-parasite systems, but illustrate the role of the most 
prevalent and relevant metazoan parasites as pathogens and diseases-related agents in European cephalopods. Thereafter, scientific focus for the different taxa which is discussed under the new challenge perspectives.

\subsection{Metazoan Parasites as Pathogens}

\subsubsection{Trematodes}

Several monogeneans have been described from European cephalopods (Hochberg 1990), but some forms were considered incertae sedis and the type material (holotype, paratype, and syntype) is not largely available. The single extent of evidence came by Llewellyn (1984), who reported gyrodactylids as epidermal browsers in the mantle cavity and on the gills of Alloteuthis squids from the North Sea and the English Channel off France and England. These monogeneans are thought to be recruited to the squids through direct contact of adults at the time of mating.

Cephalopods are also parasitized by digenean trematodes, at larval stages (metacercaria) or adults, acting as second intermediate, paratenic, or final host, but never as first intermediate host (Hochberg 1990). Metacercariae of didymozoid are the most important group of digeneans which infects oceanic squids, and some of them have been described in Illex coindetii (Fig. 12.1a) or Todaropsis eblanae in European waters (Hochberg 1990). Other groups of digenean trematodes were reported in 10 species of squids, cuttlefish, and octopus from the French and Italian coasts (Mediterranean) and from the English Channel off
France and England (Hochberg 1990). Again, the several morphs recognized present taxonomic uncertainty. Derogenes varicus were reported in Sepia officinalis in the coast of Plymouth, England, where more than $80 \%$ of the specimens over $10 \mathrm{~cm}$ mantle length appeared to be infected. Lecithochirium sp. was reported in Octopus vulgaris in the North East Atlantic, NW Spain (Fig. 12.1b-d). This hemiurid shows a fusiform body, with a sub-terminal oral sucker, a small pharynx, big acetabulum, or ventral sucker, with conspicuous acetabular cleft, and excretory vesicle with a characteristic Y-shape.

With some exceptions, most reports of trematodes in cephalopods show a low prevalence of infection, acting as paratenic hosts. Metacercaria and adult digeneans infected the digestive system (especially, the stomach and caecum) and despite they can form oval cysts with thin, transparent envelopes no significant host tissue reaction was noted.

\subsubsection{Cestodes}

Larval and post-larval stages of cestodes repeatedly have been described from European cephalopods (Hochberg 1990). The prevalence and intensity of infection are high in theuthoid squids, showing a wide range of sizes and shapes in relation to the squid host (Fig. 12.2a, b). Plerocercoid larvae belonging to the orders Tetraphyllidea and Trypanorhynchidea dominate among cestodes (Pascual et al. 1996b), which become sexually mature in the digestive tracts of elasmobranch fishes, sharks, and rays. The scolex of Tetraphyllidean larvae has characteristically four large
Fig. 12.1 Digenean trematodes from European cephalopods. Whole specimens (ventral view) of didymozoid from from Illex coindetii (a), and adult Lecitochirium sp. $(\mathbf{b}, \mathbf{c}, \mathbf{c})$ from Octopus vulgaris showing oral and ventral sucker, pharynx, acetabular cleft, and excretory vesicle. View at light microscopy (a, b), and (c, d) scanning electron microscopy (SEM). Scale bars: A: $200 \mu \mathrm{m}$; B: $200 \mu \mathrm{m}$; C. $200 \mu \mathrm{m}$; D $100 \mu \mathrm{m}$
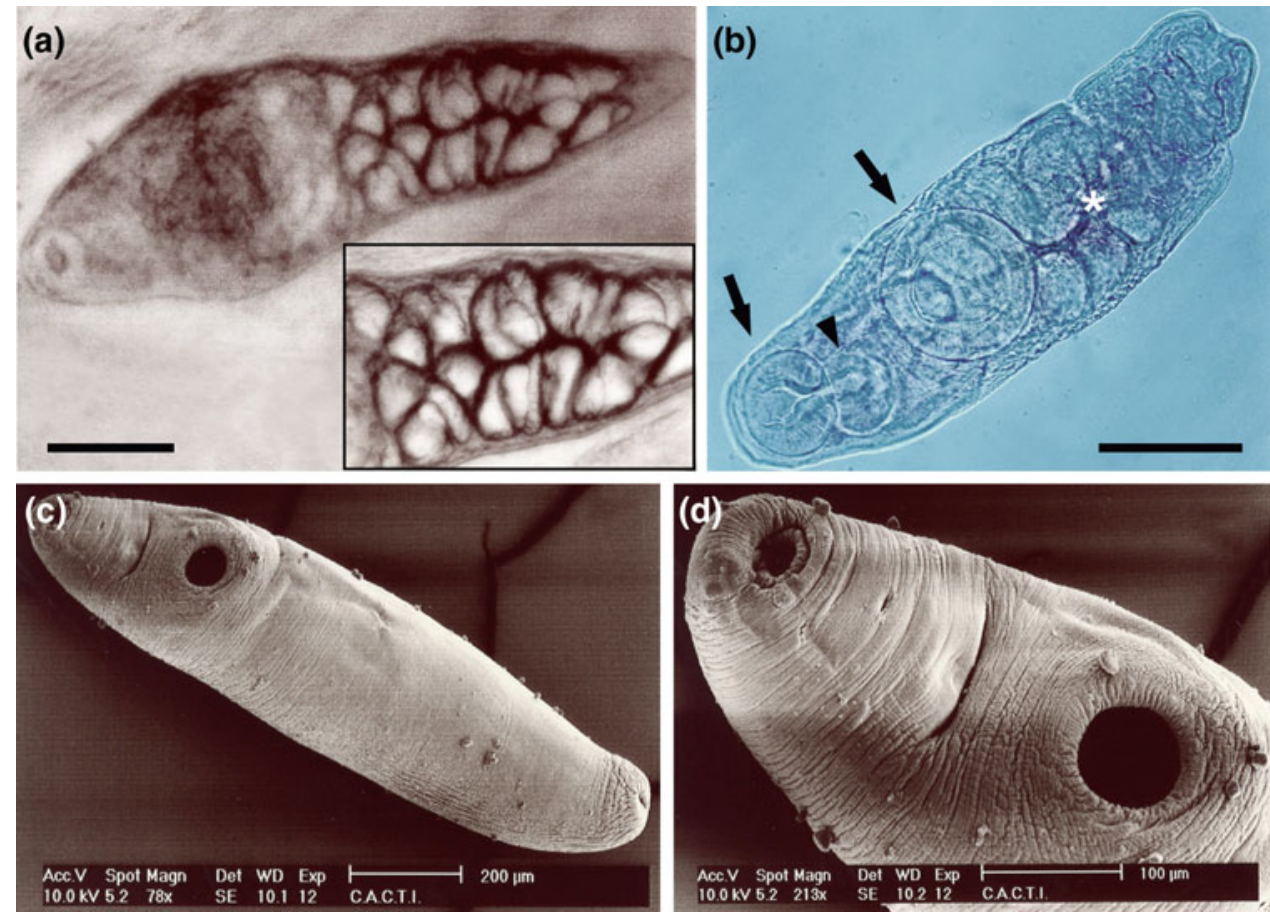
(a)

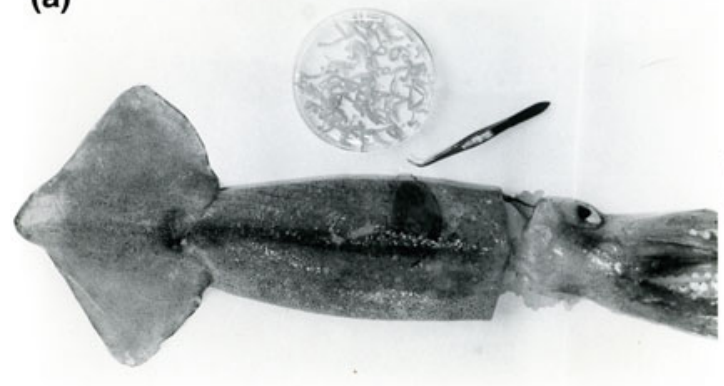

(b)

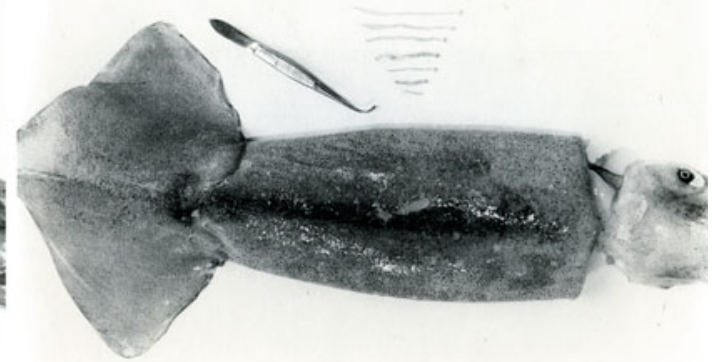

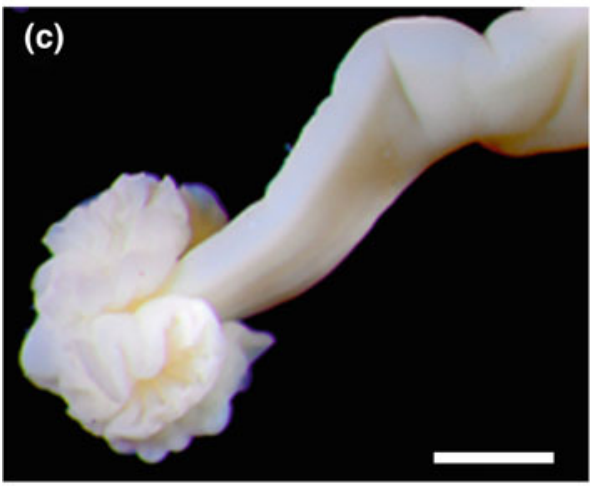

(e)

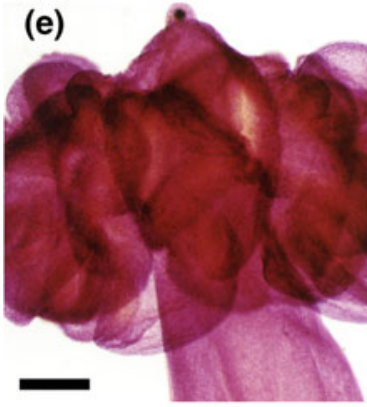

(i)
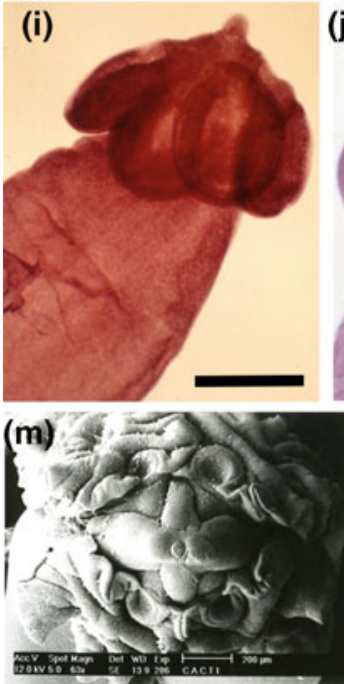

(j)
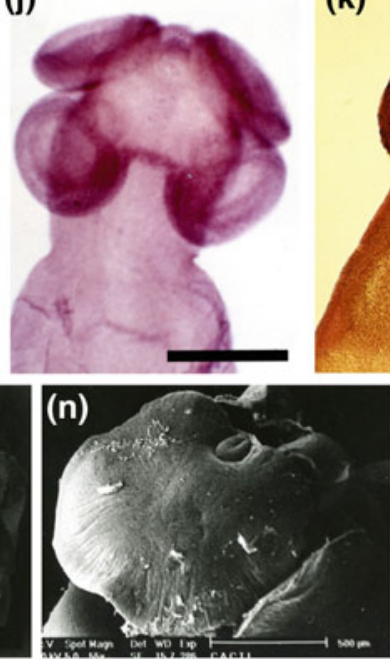

Fig. 12.2 Larval cestodes tetraphyllidean taken from a variety of cephalopod species of Europe. Note the biomass of plerocercoids (a) and the range of sizes and shapes (b) in relation to the squid host. Light microscopy of two typical body architecture of tetraphyllideans (c, d), showing the phenotypic plasticity of their scolices: with wavy-edged bothridia (e-g), smooth-oval bothridia (i-k), and scalloped-edged bothridia (l). Tegument (h) and apical and bothridial

(k)
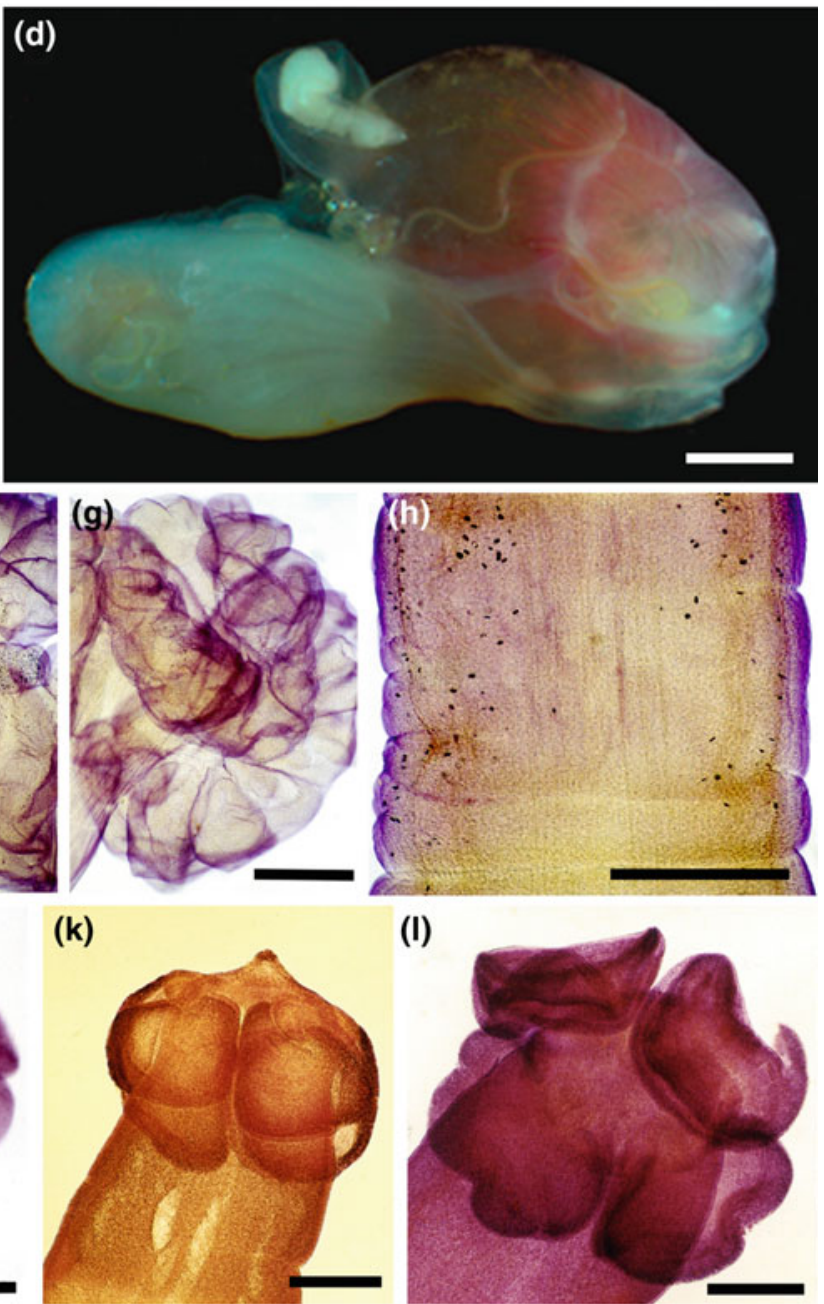

(I)
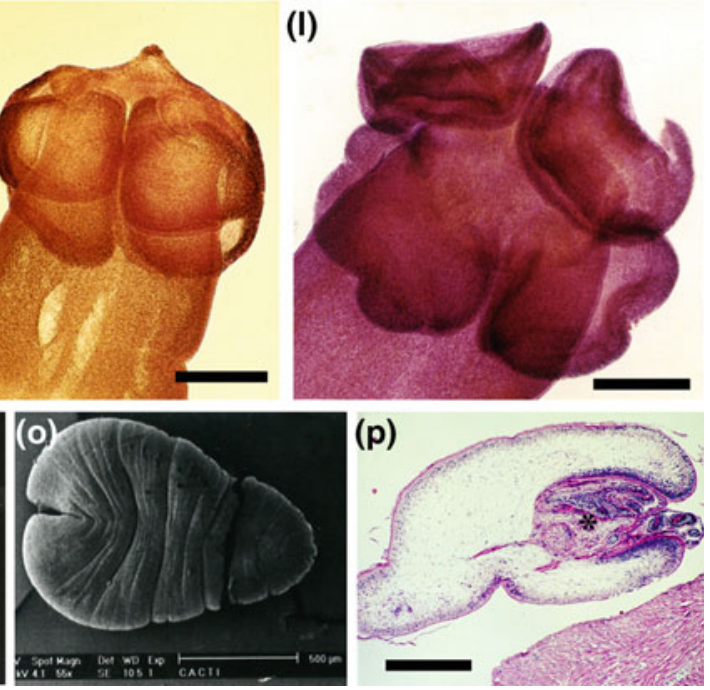

sucker in apical $(\mathbf{m}, \mathbf{n})$ view of scolex. Characteristically, in some cases, the scolices are invaginated as seen in scanning electron microscopy (o) and histological section (p). (e-h) Alcoholic Gill's Haematoxylin. (p) H\&E. Scale bars: C: $1 \mathrm{~mm}$; D: $5 \mathrm{~mm}$; E: $100 \mu \mathrm{m}$; F: $100 \mu \mathrm{m} ; \mathrm{G}: 100 \mu \mathrm{m} ; \mathrm{H}: 500 \mu \mathrm{m}$; I: $200 \mu \mathrm{m} ; \mathrm{J}: 100 \mu \mathrm{m} ; \mathrm{K}:$ $100 \mu \mathrm{m}$; L: $100 \mu \mathrm{m}$; M: $200 \mu \mathrm{m}$; N: $500 \mu \mathrm{m}$; O: $500 \mu \mathrm{m}$; P: $250 \mu \mathrm{m}$ 
leaf-like bothridia. The genus Phyllobothrium is the most common and widely dispersed in decapod and octopod cephalopods from European waters (Fig. 12.2c, d). Phyllobothriid larvae are divided into three groups by the form of their bothridia: with wavy-edged bothridia (Fig. 12.2e, g), smooth-oval bothridia (Fig. 12.2i, k), and scalloped-edged bothridia (Fig. 12.21). An apical sucker is also observed (M, $\mathrm{N})$. They show one accessory sucker by bothridia and one apical sucker. The tegument of the body is covered by microvilli or microtrics (Fig. 12.2h). Characteristically, in some cases, the scolices are invaginated (Fig. 12.2o, p).

Plerocercoids are mainly lying free in the lumen or attached to the organs of the digestive tract (stomach, caecum, and rectum) (Fig. 12.2p), although sometimes found free in the liver, mantle cavity, and even leaving the host. Plerocercoids move freely between these organs, especially when changes in temperature and other physico-chemical factors occurred in postmortem condition. This movement of large forms has been suggested to impair the marketability of the infected specimens considerably due to the unaesthetic appearance of the fish product.

Other Tetraphyllidean larvae have been reported from European cephalopods within the Scolex spp. species complex.
Despite the yet unresolved uncertainty of their taxonomic affinities, these forms are well recognized by their smaller sizes and bothridia with a characteristic number of suckers.

Larval Tetrarhynchidean metacestodes characteristically with four hook-armed tentacles are well represented by Nybelinia plercocerci in European cephalopods. Nybelinia is commonly encountered found in a variety of cephalopods in the NE Atlantic and Mediterranean cephalopods (Pascual et al. 1996a). N. lingualis (Cuvier 1817) localizes in intestinal mesenteries, on the ovary, on the linings of the coelomic cavity, and on the external covering of the stomach (Fig. 12.3a). The scolex is composed of four sessile bothridia showing four tentacles or proboscids armed by small helicoidally placed hooks (Fig. 12.3b). They can be observed evaginated (Fig. 12.3a, b, d), or invaginated into the body (Fig. 12.3c). Despite the intensity of infection can be significantly high in larger squids and the tentacles are used to anchor the host's tissues, no noticeable report on the pathological effect of these cestodes was found in the literature, with the exception of specific light infiltration of hemocytes in the infected area (Fig. 12.3e).

Most reports of cestodes in European cephalopods simply document the presence of cestodes, site of infection, sample
Fig. 12.3 Larval tetrarhynchidean of Nybelinia lingualis from a variety of hosts. Stereomicroscopy (a) and light microscopy (b) image of the typical body architecture of tetrarhynchideans, showing four sessile bothridia with four tentacles armed with hooks in spirals. Detail of the hooks observed invaginated into the body (c) or evaginated (d). Histological section showing specific light infiltration of hemocytes surrounding the infected area (e) H\&E stain. Scale bars: A: $250 \mu \mathrm{m}$; B: $250 \mu \mathrm{m}$; C: $250 \mu \mathrm{m}$; D:250 $\mu \mathrm{m}$; E: $100 \mu \mathrm{m}$
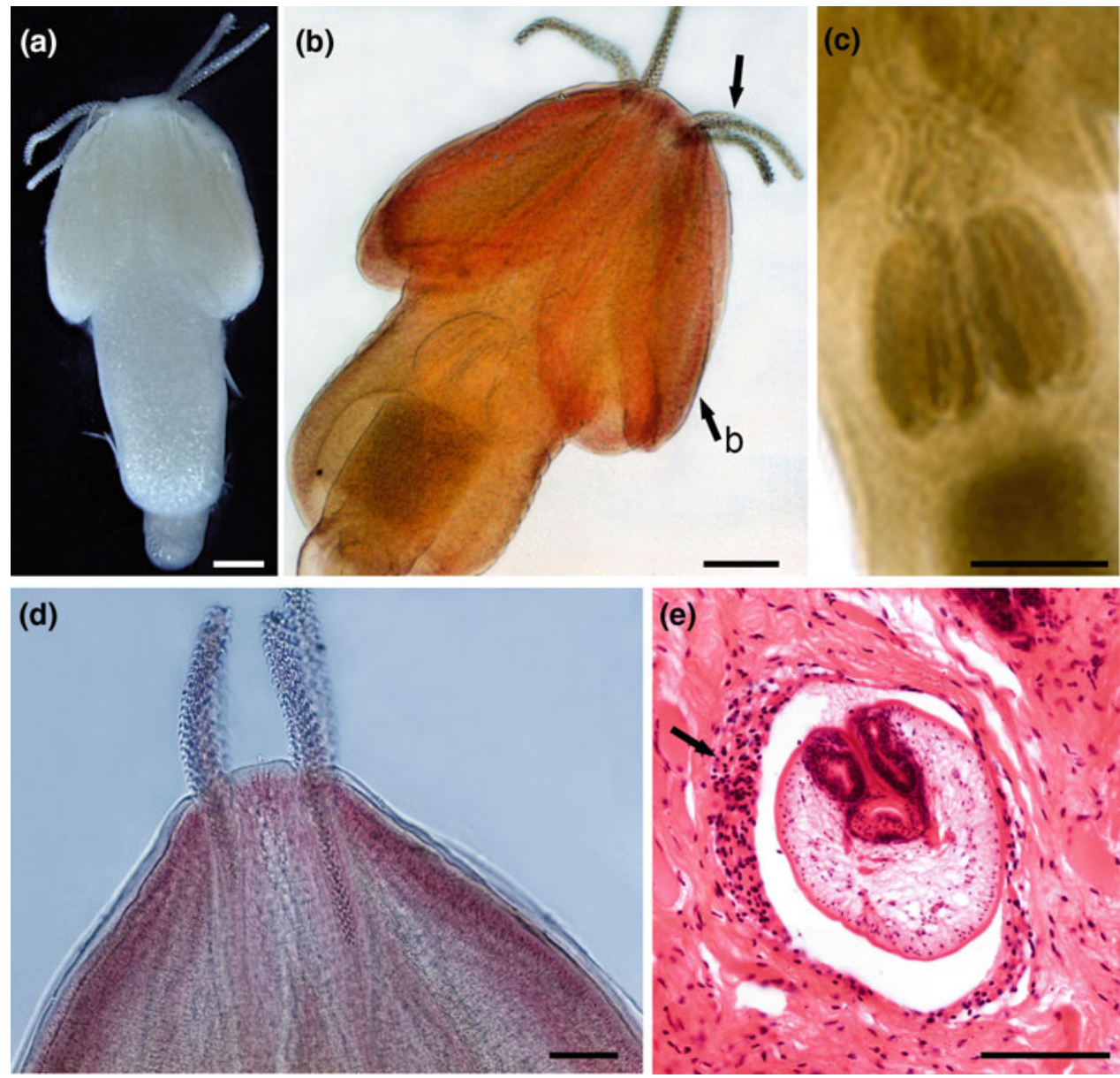
locality, and some demographic infection parameter. Despite singular effort has been concentrated on the ecological relationships of cephalopod-cestode systems (e.g., Gaevskaya and Nigmatulli 1978; Pascual et al. 1996b) as a whole neither pathological nor disease symptoms have been mentioned or figured associated to the cestode infections.

\subsubsection{Nematodes}

In the last years, larval ascaridoid nematodes are by far the most commonly reported parasitic agent in European cephalopods. Survey of anisakids with zoonotic and human allergic potential in cephalopod food products has been a target of some national surveillance plans. In fact, despite in the older literature specific identification for nematode larval types in cephalopods has been suggested as a main taxonomic concern, from the Hochberg's revision (1990) molecular methods have been largely applied to specifically identify the anisakids and their distribution in the organs and tissues of the host (Abollo et al. 2001; Melani et al. 2014; Serracca et al. 2013; Pico-Duran et al. 2016; Cost et al. 2016). Larval stages of Anisakis simplex sensu stricto and $A$. pegreffii have been identified parasitizing Octopus vulgaris, Eledone cirrhosa, Sepia officinalis, and other sepiidae species, and with higher prevalence have been identified in loliginids and ommastrephids in European waters (Abollo et al. 1998, 2001). As a rule, anisakids are found covering the outer and inner membranes of internal organs, especially the gonads (ovary and testes), nidamental glands and on the wall of stomach. Sometimes they were found on the coelomic membrane of the mantle wall (Fig. 12.4a, b). In cephalopods at fresh postmortem condition, the viable anisakid larvae can be also found actively moving within the mantle cavity. This provokes commercial rejection by consumers due to the unaesthetic appearance of squid products.

General morphological diagnostic characteristics of larval stages of Anisakis, such as anterior end showing a boring
Fig. 12.4 Anisakid nematodes from various cephalopod species in Europe. Third-larval stages are easily recognized

macroscopically (a, b) coiled and encysted in different organs (arrows). Light microscopy images of the anterior (c) and posterior (d) extremities with the characteristic ventriculus (e) of Anisakis simplex showing some morphological structures (striated cuticle, boring tooth, excretory pore, lips, esophagus, intestine, anal gland, anus, and mucron) in lateral view. Cystidicola

sp. nematode from Octopus vulgaris $(\mathbf{f}, \mathbf{g})$. Anterior (f) and posterior (g) extremities showing the characteristic pseudolabia and mucron, respectively. Scale bars: C: $50 \mu \mathrm{m}$; D: $30 \mu \mathrm{m}$; E: $150 \mu \mathrm{m}$; F: $20 \mu \mathrm{m}$; G: $20 \mu \mathrm{m}$
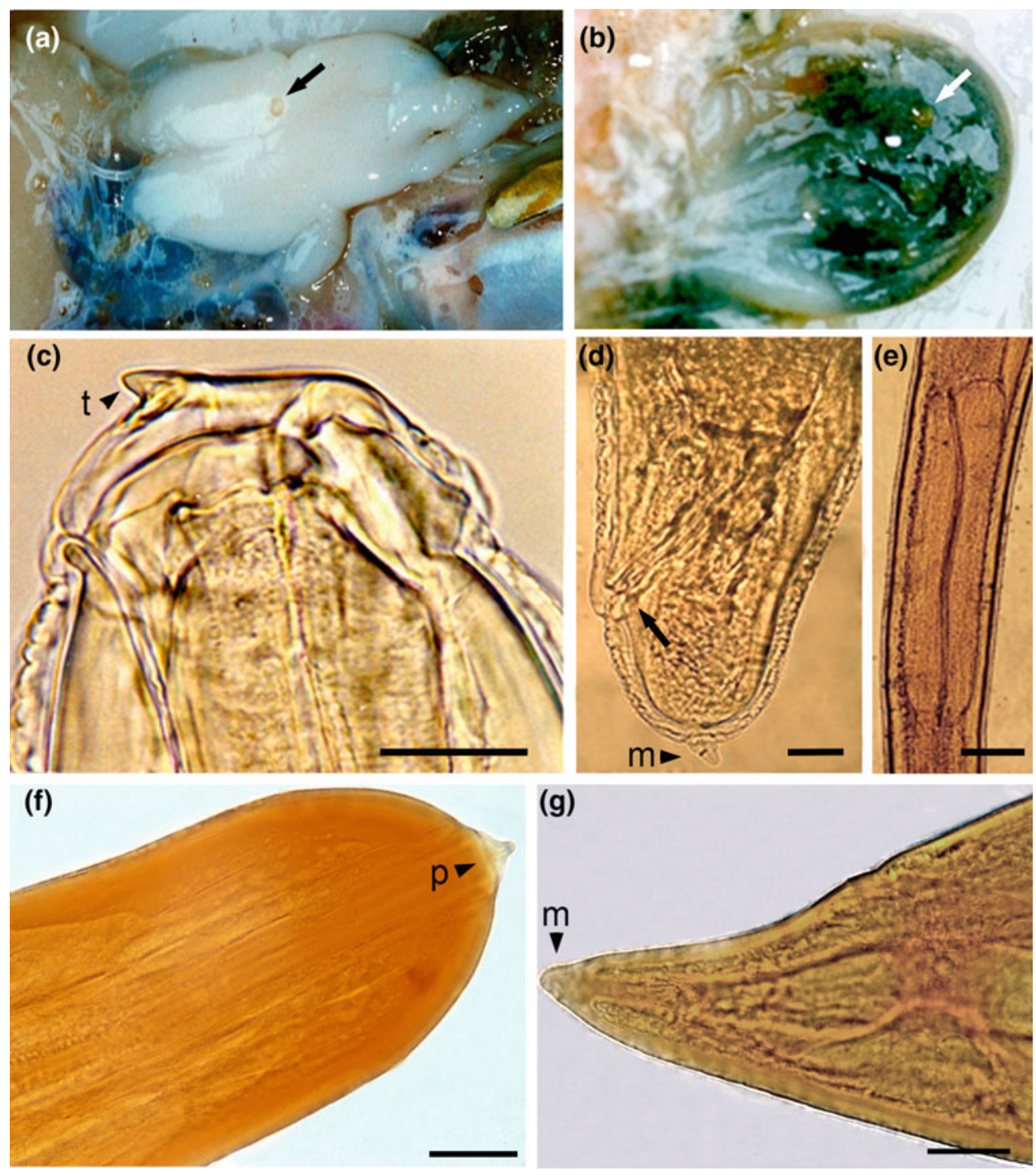
tooth, mouth, lips with papilla and excretory pore, ventriculous with specific length and shape, and tail end showing the anus and mucron terminal, are shown in Fig. 12.4c, e.

Some nematodes other than ascaridoids occasionally have been observed in European cephalopods. As an example, spirurida larval nematodes of a cystidicolid were found encapsulated in the external and internal walls of the crop, and on the connective tissue sheath surrounding the digestive gland and intestine of the common octopus $O$. vulgaris caught at NW Spain (Gestal et al. 1999a). Larval of Cystidicolidae shows mouth dorsoventrally elongated with a pair of pseudolabia with conical protuberances, two lateral cephalic alae. The esophagus shows an anterior short muscular part and posterior part longer and glandular. Post-anal tail short, with weakly nodulose truncated mucron (Fig. 12.4f, g).

Most recently, some efforts have been made to show the histopathological effect of nematode infections (Pascual et al. 1996b; Gestal et al. 1999a). Early infections consisted of necrotic tissue displaying a light inflammatory reaction followed by haemocyte infiltration. In more advanced case of infection, the response of cephalopod tissues to invading nematodes was a typical cell-mediated immune response (Ford 1992), with parasite encapsulation as an immune strategy to avoid parasite migration and destruction of host tissues (Fig. 12.5a-h). Most infected organs displayed evidence of mechanical compression and displacement of host tissue elements at sites close top or in direct contact with parasitic larvae, with varying degrees of cellular infiltration. The spaces surrounding worms were usually coated with tissue fragments, cell debris, and extensive secretion of mucous. Anisakids were thus postulated as responsible for parasitic castration in those heavily infected mature squids as a consequence of partial destruction and alteration of gonad tissues (Abollo et al. 1998).

\subsubsection{Crustaceans}

Few published reports dealt with the crustaceans infecting European cephalopods. Branchiurans and cymothoid isopods have been accidentally found on the skin and in the mantle cavity of cuttlefish (Sepia and Sepiola species). The majority of crustacean reports refer to copepods: harpacticoids of Cholydia intermedia from the mantle cavity and gills of a cirroteuthid cephalopod collected in the Faroe-Shetlands Channel; lichomolgids on the gills of Sepia officinalis and T. sagittatus from NW Mediterranean (Rosas and Banyuls) and the Adriatic (Trieste) (Hochberg 1990; Costanzo et al. 1994), and from the gills of Illex coindetii off the Atlantic coast of the Iberian Peninsula (Lopez-González and Pascual 1996); females and males of a cyclopoid copepod parasite in Octopus vulgaris from Banyuls (Hochberg 1990).

Larval stages of Lernaeoceridae assigned to Pennella varians have been largely recorded at the Mediterranean on the gills of teuthoids (L. vulgaris, T. eblanae), cuttlefish (Sepia officinalis, S. elegans, S. orbignyana, Rossia caroli, Sepietta oweniana) and octopus (Octopus vulgaris, E. moschata, Bathypolypus sponsalis) (Gestal et al. 1999b) (Fig. 12.6a-e).

Heavy infestation by the postembryonic stages of the siphonostomid copepod Pennella sp. has also been commonly reported in the gills of several commercially important cephalopod species from temperate waters of the NE Atlantic (Pascual et al. 1996a). The spatiotemporal distribution of this mesoparasitic copepod revealed a marked aggregated and seasonal pattern of parasites that fits well with their mating behavior in the gills of cephalopods (Pascual et al. 2001). Adults of the cyclopoid copepod of the genus Octopicola, Octopicula superbus have been identified in European octopuses at the English Channel, Mediterranean, and Atlantic at NW Spain (Fig. 12.6i-1).

Although in the older literature the cephalopod-copepod relationships have been categorized as highly host specific, most of the species were considered commensals. They moved on the skin (of head, arm, or mantle), mantle cavity, and gills, and feed on mucous (Fig. 12.6f-h, m-o), thereby they were considered not true parasites when affecting wild cephalopod populations. In fact, the infected cephalopods did not appear stressed and no damage to the tissues was reported. However, pennellid larvae deserve a special mention. Correlation between heavy gill infections and poorer squid condition at the infrapopulation level has also been demonstrated (Pascual et al. 2005). This work provides strong evidence that mechanical lysing of large areas of functional tissues produced by pennellids contributes to the variability in squid growth, being one of the multiple categorical predictors of size-at-age data in several infested cephalopod species commercially exploited in European waters.

\subsection{New Coming Challenges}

Modern conception of fisheries management under the Common Fishery Policy and the H2020 Research and Innovation Framework is based on two driven pillars: the ecosystem-based concept and the accommodation of fish production systems to the new seafood system challenge. The final goal is to conquer a better understanding of the natural and anthropogenic impacts on fish resources at the ecosystem level to render productive ecosystems and healthy seafood products.

\subsubsection{Seafood Security}

Parasitic diseases have been largely recognized as a bottleneck that hampers fish production systems (Shinn et al. 2014). 
Fig. 12.5 Histopathology caused by larval nematodes in various cephalopod species in Europe. Histological sections showing different aspects of the encapsulation process of nematode larvae in squids $(\mathbf{a}, \mathbf{b}, \mathbf{c}, \mathbf{d})$ and octopuses (e-h). (a) Early infection showing an encapsulated larva of Anisakis simplex with the Y-shape lateral chords, and hemocytic infiltration. (b) Histological section showing heavy hemocyte infiltration in response to the infection by larval nematodes (arrowheads). (c) Later anisakid infection showing extensive secretion of mucous in the spaces surrounding the worms.

(d) Histological section of connective-muscular tissue of the testis of squid showing mechanical compression and displacement of host tissue elements (*, cell debris). (e-h) Later infection in Octopus vulgaris showing nematodes larvae encysted in connective tissue capsule with various degrees of hemocyte infiltration.

(g) Cystidicolid larvae infecting the connective tissue of the digestive gland. (a, b, c, e, f, g) H\&E stain. (d, h) Masson's trichrome stain. Scale bars: A: $100 \mu \mathrm{m}$; B: $100 \mu \mathrm{m}$; C: $200 \mu \mathrm{m}$; D: $250 \mu \mathrm{m}$; E: $100 \mu \mathrm{m} ; \mathrm{F}: 200 \mu \mathrm{m} ; \mathrm{G}: 20 \mu \mathrm{m} ; \mathrm{H}$ : $100 \mu \mathrm{m}$
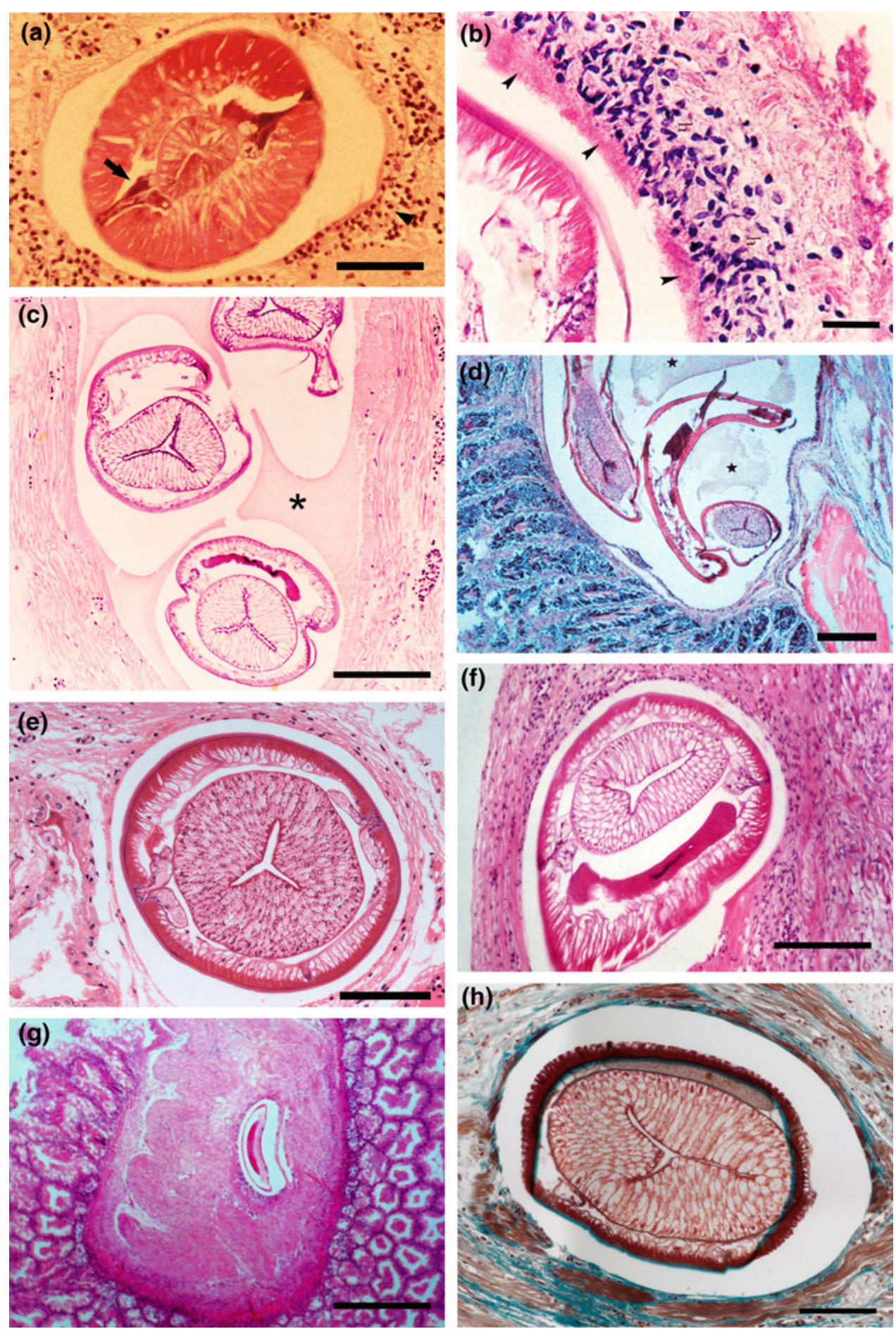

However, as it was summarized in this chapter, apart from histopathological evidences the role of metazoans as etiological agents of pathologies in cephalopod species, stocks, or individuals still remains unexplored. Of particular interest is to estimate the impact of aggregated metazoan infrapopulations on the condition and productivity of cephalopod populations, especially for those species that have fast-growing potential in open-caged systems. Similarly, considering that multiple 
Fig. 12.6 Various ontogenetic stages of the most prevalent copepod (Pennella sp.) from the gills of many cephalopod species of Europe. (a-c) Copepodid with characteristic second antenna (as); (d) chalimus with polar filament (fp); (e) free-living adult male. Histological sections of squid gills showing pennellids (arrows) associated to mechanical displacement of host tissues (f); secretion of mucous (*) (g); mating behavior (arrow) of an adult male and female (h). Lichomolgids Octopicola superbus (habitus, lateral) from the gills of octopuses (i-o). Free-living adults showing the specific morphological characters of the thorax, rostrum, and legs, with specific distribution of spiny and seta $(*)(\mathbf{i}-\mathbf{l})$. Histological sections of octopus gills showing Lichomolgids free living or anchored to the host tissue (m-o). (f-h) Masson's trichrome stain. (m-o) H\&E stain. Scale bars: A: $100 \mu \mathrm{m}$; B: $100 \mu \mathrm{m}$; C: $100 \mu \mathrm{m}$; D: $100 \mu \mathrm{m}$; E: $100 \mu \mathrm{m} ; \mathrm{F}$ : $200 \mu \mathrm{m}$; G: $200 \mu \mathrm{m} ; \mathrm{H}: 150 \mu \mathrm{m}$; I: $300 \mu \mathrm{m} ; \mathrm{J}: 300 \mu \mathrm{m}$; K: $100 \mu \mathrm{m} ; \mathrm{L}: 50 \mu \mathrm{m} ; \mathrm{M}: 200 \mu \mathrm{m}$; $\mathrm{N}: 150 \mu \mathrm{m}$
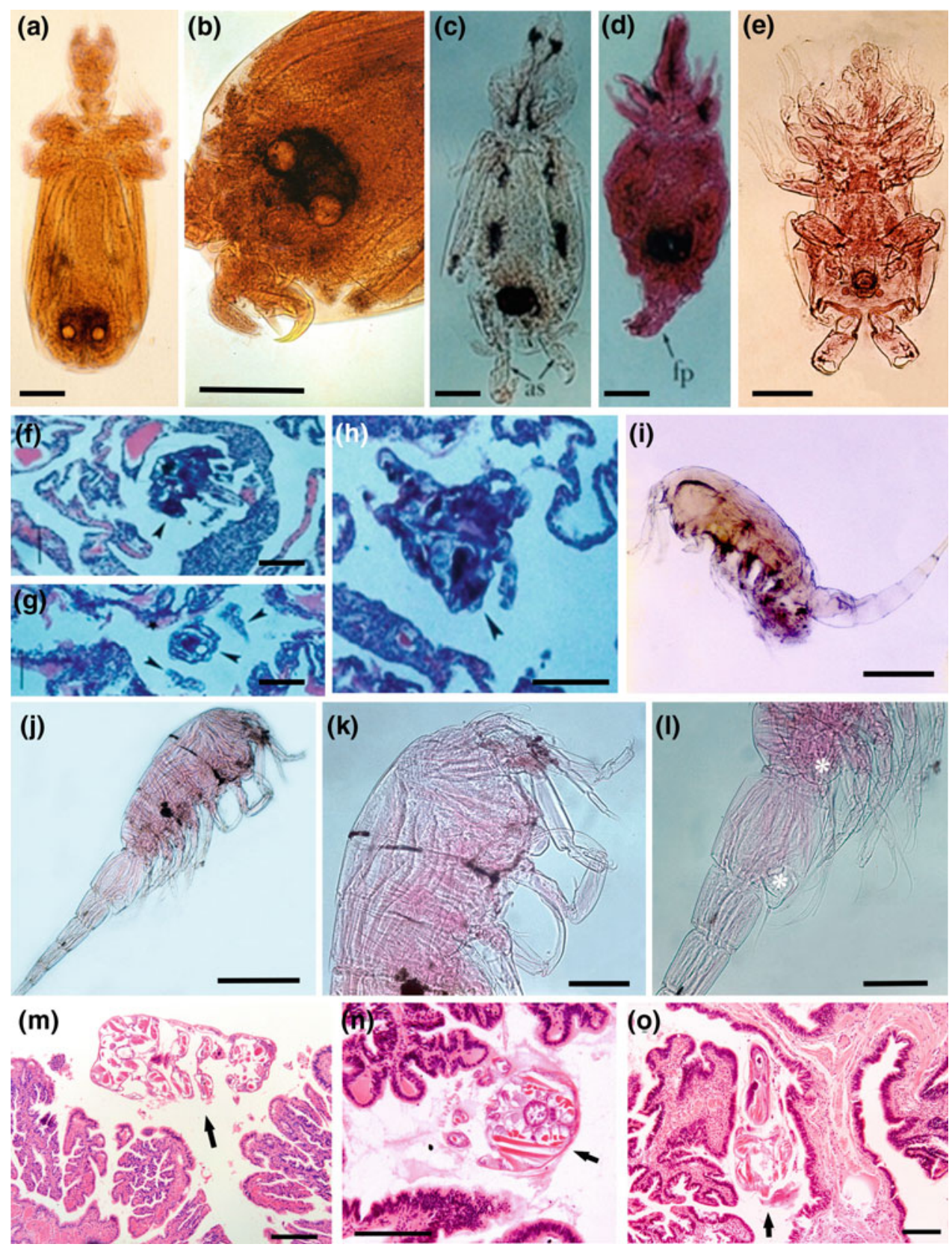

infections are common in nature, it would be desirable to analyze the synergistic/antagonistic effect of the different parasitic agents in the well-being of cephalopod populations.

\subsubsection{Seafood Safety}

Problems in the rational utilization of commercial fisheries include the management of biohazards along fish production value chains. The high pathogenicity for man of the anisakid larvae and their high prevalence and abundance in various commercially exploited fish and cephalopod species draws particular attention to this biohazard (EFSA 2010). Parasites have zoonotic potential (i.e., cause anisakidosis in humans) but also they affect the marketability of seafood products. Exposure to the anisakidosis pathogens at high rate in the mantle cavity of European squids should be properly evaluated as a causative vector in risk analysis of this emerging zoonotic and allergic disease in southern European countries (EFSA 2010).

To achieve the above challenges, systematic study on the biodiversity of the metazoan parasitic fauna of European cephalopods should clearly be a hot spot. Considering the larval stage for most recorded metazoans and in many cases the absence of type specimens, biobanking, and genetic markers are relevant tools to assure the 
identification of the etiological agent, the characterization of the hazard and the implementation of critical control points.

\subsection{Concluding Remarks}

Relatively little is known about the pathogenic potential of metazoan parasites in naturally infected cephalopods. It is stated that heavy parasitic infections may probably cause morbidity or poor condition of cephalopods but signs of disease are singularly rare with very few specimens exhibiting disease conditions. Gaevskaya and Nigmatullin (1981) suggested that the greatest injury to the cephalopod Sthenoteuthis pteropus may be done by Tentacularia larvae, large Porrocaecum (which destroy the integrity of the mantle musculature), Phyllobothrium (which assimilate part of the nutrients of the squid's food as they undergo growth and development), and anisakid larvae (which apparently destroy oocytes). Unfortunately, neither robust scientific evidence nor available material is available to support this statement.

As a whole, judging by the magnitude of the extent/intensity of infection, the site of infection, and the fact they can undergo growth, it seems that metazoans may deplete energy stores of infected cephalopods, which are directed toward tissue repair and the host's defense mechanisms. Parasitic infection may thus be considered an environmental stressor and as such a source of uncertainty in the evaluation of the potential productivity of cephalopod populations (Pascual et al. 2007a, b, c).

\section{References}

Abollo E, Gestal C, López A, González A, Guerra A, Pascual S (1998) Squid as trophic bridges for parasite flow within marine ecosystems: the case of Anisakis simplex (Nematoda: Anisakidae), or when the wrong way can be right. S Afr J Mar Sci 20:223-232

Abollo E, Gestal C, Pascual S (2001) Anisakis infestation in marine fish and cephalopods from Galician waters: an updated perspective. Parasitol Res 87:492-499

Cost A, Cammilleri G, Graci S, Buscemi MD et al (2016) Survey on the presence of $A$. simplex s.s. and A. pegreffii hybrid forms in Central-Western Mediterranean Sea. Parasitol Inter 65 (6):696-701

Costanzo G, Calafiore N, Crescenti N (1994) Copepodids of Doridicola longicauda (Claus, 1860) (Copepoda: Poecilostomatoida: Lichomolgidae) associated with Sepia officinalis L. J Crust Biol 14(3):601-608

European Food Safety Agency (2010) Scientific opinion on risk assessment of parasites in fishery products. EFSA 8(4):1543

Ford L (1992) Host defense mechanisms of cephalopods. Annu Rev Fish Disea 1:25-41

Gaevskaya AV, Nigmatullin CM (1978) The helminth fauna ofAtlantic squids of the Family Ommastrephidae (Cephalopoda: Oegopsida). Malcol Rev 11:134-135
Gaevskaya AV, Nigmatullin CM (1981) Several ecological aspects of the parasitic relationships of the flying squid (Sthenoteuthis pteropus, Steenstrup, 1855). (In Russian). Biol. Nauki (Mosk.) 1:52-57. (Translation available from F.G. Hochberg)

Gestal C, Abollo E, Arias C, Pascual S (1999a) Larval nematodes (Spiruroidea: Cystidicolidae) in Octopus vulgaris (Mollusca: Cephalopoda: Octopodidae) from Northeastern Atlantic Ocean. J Parasitol 85(3):508-511

Gestal C, Belcari P, Abollo E, Pascual S. (1999b) Parasites of cephalopods in the northern Thyrrenian Sea (Western Mediterranean): new host records and host specificity. Sci Mar 63 (1):39-43

González AF, Pascual S, Gestal C, Abollo E, Guerra A (2003) What makes a cephalopod a suitable host for parasites? The case of Galician waters. Fish Res 60(1):177-183

González AF, Rodríguez H, Outeiriño L, Vello C, Larsson C, Pascual S (2018) A biobanking platform for fish-borne zoonotic parasites: a traceable system to preserve samples, data and money. Fish Res 202:29-37

Gregori M, Roura A, Abollo E, González AF, Pascual S (2015) Anisakis simplex complex (Nematoda: Anisakidae) in zooplankton communities from temperate NE Atlantic waters. J Nat Hist 49(1314):755-773

Hochberg FG (1990) Diseases of Mollusca: Cephalopoda (Diseases caused by protistans and metazoans). In: Kinne O (ed), pp 47-200. Diseases of Marine Animals. Biologische Anstalt Helgoland, Germany

Kuhn T, Cunze S, Kochmann J, Klimpel S (2016) Environmental variables and definitive host distribution: a habitat suitability modelling for endohelminth parasites in the marine realm. Sci Rep 6:30246

Llewellyn J (1984) The biology of Isancistrum subulatae n. sp. a monogenean parasitic on the squid, Alloteuthis subulata, at Plymouth. J Mar Biol Ass UK 64:285-302

López-González J, Pascual S (1996) A new species of Stellicola Kossmann, 1877 (Copepoda, Lichomolgidae) associated with the squid Illex coindetii (Cephalopoda, Ommastrephidae) in the Atlantic Ocean. Hydrobiol 336:1-6

Meloni M, Ángelucci G, Merella P, Siddi R, Deiana C, Orru G, Salati F (2014) Molecular characterization of Anisakis larvae from fish cuaght off Sardinia. J Parasitol 97(5):908-914

Pascual S, González AF (2007) Parasite recruitment and oceanographic regime: evidence suggesting a relationship on a global scale. Biol Rev Camb Philo Soc 82(2):257-63

Pascual S, Guerra A (2003) Vexing question on fisheries research: the study of cephalopods and their parasites. Iberus 19(2):87-95

Pascual S, González AF, Arias C, Guerra A (1996a) Biotic relationships of Illex coindetii and Todaropsis eblanae (Cephalopoda, Ommastrephidae) in the Northeastern Atlantic: evidence from parasites. Sarsia 81:265-274

Pascual S, Gestal C, Estévez JM, Rodríguez H, Soto M, Abollo Arias C (1996b) Parasites in commercially-exploited Cephalopods (Mollusca, Cephalopoda) in Spain: an updated perspective. Aquacul 142:1-10

Pascual S, González AF, Gestal C, Abollo E, Guerra A (2001) Epidemiology of Pennella sp. (Crustacea: Copepoda) in exploited Illex coindetii stock in the NE Atlantic. Sci Mar 65 (4):307-312

Pascual S, González AF, Guerra A (2005) The recruitment of gill-infecting Pennella (Crustacea, Copepoda) as a categorical predictor of size-at-age data in squid populations. ICES J Mar Sci 62:629-633

Pascual S, Gestal C, Abollo E, Arias C (2007a) 9 Effect of Pennella sp. (Copepoda, Pennellidae) on the condition of Illex coindetii and Todaropsis eblanae (Cephalopoda, Ommastrephidae). Bull Europ Assoc Fish Pathol 17 (3/4):91-95 
Pascual S, González AF, Guerra A (2007b) Parasites and cephalopod fisheries uncertainty: towards a waterfall understanding. Rev Fish Biol Fish 17:139-144

Pascual S, González AF, Guerra A (2007c) Parasite Recruitment and Oceanographic Regime: a working hypothesis on a global. Biol Rev $82: 257-263$

Pico-Duran G, Pulleiro-Potel L, Abollo E, Pascual S, Muñoz P (2016) Molecular identification of Anisakis and Hysterothylacium larvae in commercial cephalopods from the Spanish Mediterranean Coast. Vet Parasitol 220:47-53

Puerta P, Hunsicker ME, Quetglas A, Álvarez-Berastegui D, Esteban A, González M, Hidalgo M (2015) Spatially explicit modelling reveals cephalopod distributions match contrasting trophic pathways in the Western Mediterranean Sea. PLoS ONE 10(7):e013343

Rohde K (2002) Ecology and biogeography of marine parasites. Adv Mar Biol 43:1-86

Serracca L, Cencetti E, Battistini R, Rossini I et al. (2013) Survey on the presence of Anisalis and Hysterothylacium larvae in fishes and quids caught in Ligurian Sea. Vet Parasitol 196(83-4):547-51

Shinn AP, Pratoomyot J, Bron JE, Paladini G, Brooker EE, Brooker AJ (2014) Economic costs of protistan and metazoan parasites to global mariculture. Parasitol 142:196-270. https://doi.org/10.1017/ S0031182014001437
Open Access This chapter is licensed under the terms of the Creative Commons Attribution 4.0 International License (http:// creativecommons.org/licenses/by/4.0/), which permits use, sharing, adaptation, distribution and reproduction in any medium or format, as long as you give appropriate credit to the original author(s) and the source, provide a link to the Creative Commons licence and indicate if changes were made.
The images or other third party material in this chapter are included in the chapter's Creative Commons licence, unless indicated otherwise in a credit line to the material. If material is not included in the chapter's Creative Commons licence and your intended use is not permitted by statutory regulation or exceeds the permitted use, you will need to obtain permission directly from the copyright holder. 